\title{
Věčný návrat téhož a časovost \\ u Ladislava Klímy
}

\section{Eternal Recurrence and Relation to Time of Ladislav Klíma}

\author{
Jan Kratochvíl
}

\begin{abstract}
Abstrakt
Článek se zabývá pojetím věčného návratu téhož a časovostí ve filozofii Ladislava Klímy. Analyzuje logickou nesoudržnost Klímova pojetí věčného návratu téhož, která vyplývá z podmínek stanovených takovým způsobem, že nemohou korespondovat s proklamovaným závěrem. Nicméně Klímovo filozofování o čase má spíše existenciální rozměr a věcná analýza mu není zcela úměrnou metodou. V další části článku je tedy do kontextu předchozího výkladu zasazen literární obraz beznohého žebráka, který v Klímových prózách čas představuje, a je vyložena jeho specifická symbolická role v "egosolistickém” vztahu k časovosti.
\end{abstract}

\section{Klíčová slova}

Ladislav Klíma, mýtus o věčném návratu, čas, časovost

\begin{abstract}
This article is dealing with the meaning of the eternal recurrence and the reason of time in philosophical work of Ladislav Klíma. Klíma's understanding of eternal recurrence contains logical inconsistencies which are being analysed. The conditions established by Klíma do not agree with results which are concluded. Nevertheless, the point of Klíma's relation to time is more existential and the logic analysis is not proportional to the sense of so called "egosolism". Klíma's literary image of time which is shown as a legless beggar is established to the previous ideas of eternal recurrence analyses, too. Its role in the specific confession of Klíma's philosophy is explained as well.
\end{abstract}

\section{Keywords}

Ladislav Klíma, eternal recurrence, time, relation to time 
V přrištím roce si připomeneme 140 let od narození „enfant terrible“ české filozofie, Ladislava Klímy, jakož i 90 let od jeho úmrtí. Není nikterak snadné rozplétat pavučinu argumentů, pseudoargumentů a obecných axiomatických proklamací, jimiž se způsob Klímova filozofování vyznačuje, ale snad i to je důvod, proč se jeho dílo, jehož základní obrysy jsou rozvrženy v traktátu Svět jako vědomi a nic, dosud těší určitému zájmu. ${ }^{1}$

Následující článek rekonstruuje Klímovo pojetí mýtu o věčném návratu téhož, jak jej lze vysledovat právě z uvedené autorovy prvotiny. Odtud pak vykračuje k širšímu pojetí časovosti, která názorně ilustruje své kontury v Klímově díle literárním.

\section{Meze mýtu o věčném návratu}

Jedním z ústředních ontologických pojmů Klímovy filozofie je tzv. „univerzální vědomí“. Shrňme, co Klíma tvrdí o jeho povaze:

1) Je určité počitatelné množství, které tvoří kosmické vědomí, tedy svět. Základním prvkem tohoto množství je „myšlenkový atom“.2

2) Tyto prvky se porůznu kombinují. ${ }^{3}$

3) Toto kombinování je nekonečný proces. ${ }^{4}$

Nyní se pokusme prozkoumat, nakolik jsou Klímou stanovené podmínky konzistentní a nakolik z nich nutně vyplývá myšlenka „věčného návratu téhož“. Pro tento účel definujme pojem „věčnost“ jako nekonečný proces.

Pojem „nekonečný“ je ovšem paradoxní povahy a myšlenka „věčného návratu téhož“ s ním souvisí jen potud, pokud se kombinace prvků děje podle nějakého vnitřního řádu tak, aby se mohla vytvořit perioda (onen „světový rok“). Pro začátek předpokládejme, že se prvky kombinují podle nějaké vnitř̌-

1 Klíma sám se $\mathrm{k}$ chybám své prvotiny v předmluvě k jejímu druhému vydání typicky nezaměnitelným způsobem hrdě přihlásil, ačkoliv jen těžko soudit, co chybami konkrétně myslel: „Však dosti! - V tomto 2. vydání nezměnil principielně ni slovo ni hlásku; nekorrigoval by ani pravopisně ani ,kobilu‘ -, chyba myšlenková není méně důležitá než orthografická, ale chyb myšlenkových jsou zde a všude myriády; a myšlenka sama je chyba.“ Ladislav Klíma, Svět jako vědomi a nic, 3. vyd., Praha: Trigon 1990, s. 12.

2 „Z nekonečnosti času a konečnosti quanta kosmického vědomí následuje nutně Nietzscheův věčný návrat téhož." Tamtéž, s. 32.

3 „Každý myšlenkový atom sloučí se průběhem světového roku se VŠEMI myšlenkovými atomy a STANE SE TAK ZA DOBU SVĚTOVÉHO ROKU TÍM, ČÍM JE SVĚT V KAŽDÉM MOMENTU.“ Tamtéž, s. 40.

4 „A pak začne tento př́íšerný svět otáčet se znovu..., a po věčnosti věčností..." Tamtêž, s. 41. 
ní nutnosti (např. „přírodních zákonư“ či „fikcí vědomi“, označení není důležité). Je-li pak konečný počet kvant roven $n$, pak i počet kombinací je konečné číslo $n !$. Jakákoliv perioda vyjádřená kombinací kvant, jejichž počet je nižší $n$ !, může představovat věčně se vracející velký světový rok. Tato myšlenka nevyžaduje nutně realizaci všeho, jen nekonečně se opakující totéž.

Problém se ovšem komplikuje, má-li být světový rok roven $n !$, jak požaduje Klíma. Znamená to tedy, že jakákoliv myslitelná kombinace kvant prvků (předpokládejme, ačkoliv to není nutné, že není možné uvažovat o nemyslitelném a že to z definice nedělal ani Klíma, ačkoliv o tom často píše $)^{5}$ jednou nutně nebude pouze myslitelnou možností, ale stane se provždy skutečností. Pravděpodobnost jisté podoby světa je 1:n!. Další světový rok musí pak nastávat s pravděpodobností 1:n!-1 a tak dále, až k 1:n!-(n!-1), tedy k situaci, kdy je konkrétní kombinace kvant prvků jistá. Pak nastává perioda.

Ovšem zkusme si představit následující příklad. Může být svět, v němž mám jinou barvu očí, než aktuálně mám? Vše ostatní zůstává zcela stejné až na tento detail. Tato možnost je zahrnuta $\mathrm{v} n$ ! a měla by se jednou realizovat, má-li se realizovat opravdu vše. Může se ale opravdu realizovat? Muselo by někde dojít k narušení „ř́ádu“, který udává, že barva mých očí je výsledkem předchozí kombinace kvant prvků ve světě, že zkrátka genetické zákony někde udělaly „nevysvětlitelnou“ chybu, tedy došlo k náhodné kombinaci. Je-li svět bez náhody a je-li vše, co se v něm děje, výsledkem postižitelných, ačkoliv nepoznaných procesů, ve kterých třeba vystupuje obrovské množství proměnných, pak nemůže být realizován svět, v němž mám jinou barvu očí a všechno ostatní (v tomto př́ípadě zejména způsob kombinace genů, který vedl právě k mému početí v konkrétním čase) zůstane beze změny.

Přistoupím-li na věčný návrat téhož, musím se smíriti i s tím, že budu mít věčně i tuto barvu očí v navěky se otáčejícím koloběhu kombinace kvant prvků ve „světovém roce“? Nemusím, mohu si představit, že myslitelné náhodné procesy nejsou tak docela náhodné, ale střídají se podle striktního řádu, který zajištuje realizaci všech myslitelných kombinací. Pak ale přijdu o možnost mít právě tuto barvu očí v jiném časovém poměru $\mathrm{k}$ dalším událostem. Poměr musí být zachován, nebo se jeho varianty musí opět stř́ídat podle nějaké vnitřní nutnosti. Úvaha začíná vytvářet donekonečna se tyčící pyramidu hierarchie světových roků s přirozeně donekonečna se rozšiřující základnou, $\mathrm{v}$ nichž se realizují všechny možnosti v poměru k realizaci všech možností

5 „V patnáctém roce procitla, jednoho osudného odpoledne, rázem a děsivě má dosud spící podstata pod jednou ze svých forem: musit násilně myslit o nemyslitelnostech.“ L. Klíma, Vteřiny věčnosti: prózy, listy, eseje, sentence, Praha: Odeon 1967, s. 270. 
v jiném uspořádání. Tato pyramida ovšem není nekonečná, je jen donekonečna běžící. Do nekonečna ovšem nelze doběhnout, byt bych měl k dispozici nekonečné množství kroků. Problém je v tom, že běžím (střídám varianty kvant). Stejně tak nejde do nekonečna napočítat, i kdybych počítal věčně.

Vstoupíli do hry prvek náhody, pak se svět, v němž mám jinou barvu očí a vše je jinak zcela stejné (včetně nějakého z výše uvedeného řádu vybočujícího poměru k jiným světovým letům), jednou může stát skutečností. Náhoda však představuje pro věčný návrat téhož smrtelné nebezpečí.

Mám-li mít před sebou skutečně nekonečný rozvrh bez vnitřní nutnosti (a tedy zahrnující prvek náhody), pak narazím na paradox. Pravděpodobnost, že určitá kombinace kvant bude vždy 1:n! a pravděpodobnost, že svět se bude vyskytovat v podobě kombinace kvant $x$, kdy $x$ představuje stav světa odlišitelný od jakéhokoliv jiného stavu světa ${ }^{6} y$, pak se všechny myslitelné kombinace vystřídají pouze s donekonečna rostoucí pravděpodobností. Ovšem vzhledem k tomu, že čas má k dispozici nekonečné množství „pokusů“, pak je nekonečně pravděpodobné i to, že dojde k realizaci nekonečně nepravděpodobných variant, jichž je nekonečné množství. Z tohoto hlediska je cokoliv aktuálního (aktuální stav kombinace kvant prvků) nekonečně pravděpodobné i nepravděpodobné. Čas by zkrátka mohl vytvořit nekonečnou neperiodickou řadu událostí, pak by ale nemohl být nahlížen jako věčná obměna počitatelného množství kvant, tedy jako věčný návrat téhož.

\section{Kudy z děravé kapsy}

„Věčnost není děravá kapsa, aby se z ní něco ztratilo. "7 Snad není, ale pak se do ní zcela jistě nevejde všechno, nebot skutečné „všechno“ nemá hranic, aby se vešlo do kapsy. Do kapsy se vejde jen úhledně spořádané, periodou ohraničené „všechno“. Anebo se do ní opravdu všechno vejde, a je to každé „všechno“, tedy všechna „všechna“. Pak ta kapsa ale musí být bezedná, a to se z ní něco ztrácí pořád.

6 Pohlížím-li na svět jako na proud kombinujících se kvant, dostávám se na ošidnou půdu Zenónových aporií. Musím definovat jistou aktuální podobu kvant, nějaké nikoliv nekonečně malé „ted"“, které odliším od jiného nekonečně malého „ted"“ v čase, který nemůže být složením těchto strnulých „ted““, ale plynoucím kontinuem.

7 Erik Gilk - Jiří Hrabal (eds.), Věčnost neni děravá kapsa, aby se z ní něco ztratilo / Soubor studii věnovaných Ladislavu Klímovi, Olomouc: Aluze 2010. 
Klímova filozofie je ovšem zcela proklamativně ${ }^{8}$ na hony vzdálena nějakému přesnému vyšetřování pojmů a jejich vztahů. Její akcent je etický, je výzvou, nikoliv popisem. A ačkoliv se mýtus věčného návratu téhož neslučuje s realizací všech kombinací kvant prvků, pokusme se definovat konfesi egodeismu vzhledem $\mathrm{k}$ výše řečenému.

Představíme-li si ještě jednou donekonečna se rozbíhající pyramidu realizovaných „věčností“, pak nechme z přímek, jež vymezují její hrany, vzrůst roviny, $\mathrm{z}$ nich prostory, a odtud vykročme k nekonečnému množství dalších, a pochopitelně nemyslitelných, nepředstavitelných, jen jako verbální hř́ičku opsatelných rozměrů, v nichž by se v témže jediném „okamžiku“ realizovalo další nekonečné množství nekonečných množství věčností. V každém bodě nekonečných přímek se v témže „čase“ realizuje nekonečné množství možností kombinací a $\mathrm{v}$ jeho každém bodě opět nekonečné množství. Taková úvaha zcela ruší čas jako následnost čehokoliv: „Viděn sub specie meae aeternitatis je tento malý život jen jednou z miliónů knih v bibliothece, kterou, chci-li, mohu číst, chci-li, zas na její místo nedotčenou postavit. Všechny knihy nestojí za čtení; ale je dědičný hřích, dědičná hovadskost člověčenstva, že věří, že právě jen tahle jediná knížečka, ceny velmi problematické, musí být dočtena do konce. ,Podlehnutím“ nazval bych právě toto podlehnutí dědičné hovadskosti."9

Nikoliv milióny (což je snad od Klímy jen literární obrat), ale nekonečno „knih“ musí být v „bibliothece“. Všechny by pak byly čteny naráz dokonale stejným i dokonale jiným způsobem.

Avšak kým čteny, když svưj aktuální život zakouším jako četbu právě té jedné knihy, jež je psána jazykem časovosti? Na tuto otázku Klíma odpovídá tak, že má „subjektivita“ je iluzivní „úskok“ mého myšlení tváří v tvář věčnosti, nebot myšlenka „donekonečna explodujících přímek pyramidy“ je nemyslitelná. K dispozici je jen takový svět, který zachovává formu zkušenosti, nebot’ rozum, obratný lhář, lže v tomto mýtu tak, že mu nemožno nevěřit. ${ }^{10}$

8 „Fragmentární způsob myšlení, [...], aforistický způsob psaní jsou jedině zdrávy.“ L. Klíma, Svět jako vědomi a nic..., s. 17.

9 L. Klíma, Filosofické listy, Praha: Herrmann 1993, s. 15.

10 „...náš intellekt je nepřirovnatelný lhář ze řemesla, což dokazuje i tím, že lže tak přesvědčivě, že nemožno hanebnému taškáři nevěřit..." L. Klíma, Svět jako vědomi a nic..., s. 21. 


\section{Beznohý žebrák}

V rámci Klímova egodeismu je nám dáno žít ve světě, jenž je iluzí, avšak jeho iluzivnost nelze prokázat, tím méně vyvrátit. Co tedy zbývá, než definovat vztah zakoušené vůle k této iluzi jako etický apel?!11 Jedině lhostejná hravost, vlastní velkým kočkám, ${ }^{12}$ nepohnuté rozšafné Sebebožství, Klímou nazývané ludibrionismus, ${ }^{13}$ je vztah k prožívané skutečnosti, který je hoden úsilí. Jeho součástí je pak i překonání jednoho z největších paradoxů popsané filozofie - neiluzornost vlastního Božství tam, kde je iluzorní vše. V pravdivé Sebebožství, které je stavěno do opozice vůči ne-sebebožsky zakoušenému světu, lze pak jen zcela nábožensky uvěřit.

Klíma filozoficky osciluje mezi polohou světce a věrozvěsta této specifické konfese, jejíž součástí je za osvíceného se považovat. Co je čas tomuto proroku, jemuž má být osobně zakoušená vůle vưlí světa? Nejpřiléhavější odpověd' nalezneme snad v obraze př́ǐsery, která vystupuje v jeho prózách:

11 Analýza samotného Klímova vztahu od vlastní extatické cesty egodeismu k jeho vidění jako univerzálního etického apelu přesahuje svým rozsahem možnosti tohoto textu. Omezím se jen na citaci reprezentující vlastní účtování s duševním zápolením (snad poznamenané psychiatrickou chorobou): „Moje zuřivě vášnivé praktikování filosofie nebylo marné. - Ǩíkal jsem si sice až do čtyřicátého roku, že jsem zde ztroskotal - nedosáhnuv na dosah ruky ležícího Cíle cílů: věčné, klidné, nezranitelné Radosti a Záře - nedosáhnuv vše, myslil jsem, že jsem nedosáhl nic. Ale třeba ne vše, přece jen mnoho. Mám právo nazývat se filosofem aspoň takové jako Xenokrates, Diogenes, Epiktet - A žiju v nepřirovnatelně horších podmínkách - Když jsem onomu Böhlerovi řekl, že jsem Cíle naprosto nedosáhl, když on mně odpověděl: ,Kdo jiný od vzniku lidstva než ty?‘, vysmál jsem se mu. Ale později chápal jsem stále víc, že měl trošku pravdy. Absolutnost (kterou jsem já skrz naskrz) opovrhuje každou relativností. Já vede k sebepodceňování já. - Nejsem nic jiného než ustavičné (často, přečasto i ve snu) práskání bičem mé Absolutní, absolutně komandující a do věčnosti v Sobě se koupající vůle, a zběsilý, „nerozumný“, ale vždy víceméně poslušný rej myšlenek a všech duševních stavů, - můj život největším bláznovstvím, donkichotérií, jaká myslitelna, - proto, že je zároveň maximálně racionelní, - proto ještě žiju, „měsíčan“ spadlý na zem, jehož jediná činnost, ani minutu neustávající, byla důsledné pracování proti podmínkám animálního života.“ L. Klíma, Vteřiny věčnosti..., s. 280-281. - A v podstatě univerzální etický apel, kdy se cesta k nedosažitelnému cíli stává každému výzvou, jak žít: „Kdybys místo ,bezpočtu“ svých argumentů měl jen jeden, ale zato skutečně dokazující, lépe by bylo pro tebe, ubohý! Nebot já, čtenář, ujištuji tě, že navzdor všem tvým důkazům mé neexistence existuji.“ „Ale monsieur, což nepochopil jste dosud, že právě to pravím Vám já?... tj. něco ve Vás, co těmito literami, Vašimi jen představami, káže Vám konečně Sebepoznání?“ L. Klíma, Traktáty a diktáty, Olomouc: Votobia 1995, s. 277.

12 Srovnej např. L. Klíma, Velký roman [sic], Praha: Torst 1996, s. 111.

13 Viz např. L. Klíma, Filosofické listy..., s. 40. 
„Asi 10 kroků před nimi šoural se směrem k nim beznohý muž - tak pomalu, tak jednostejně, tak přišserně, jako rafije na velikém orloji.

„Nazpět!“ zvolal Edgar a Eura uposlechla. Rychle seskákali dolů přes kameny a skály.

„Neu-tí-kejte, mně ne-u-te-če-te, mně - nic neu-teče, já do-ho-ním - vše-cko,“ znělo strašně za nimi.

Doběhli štastně k rozcestí, aniž by byli upadli. „Nalevo!“ vzkřikl Edgar. „Na břehu by nás dostihli!““

A dali se nalevo.

„Ses-tro - ne-pusť - je tam - nadežeň mně je sem - já - je - zde - uš-kr-tím - a poz-řu-," znělo za nimi. "14

Netvor, bez nohou kráčející, odsekává hlasem stejnoměrné kusy svých obludných promluv. Je totožný se zanikáním a smrtí, jejíž je rodným bratrem.

Otázka však nezní, zda tento příšerný žebrák obchází na své cestě nekonečný kruh, či kráčí lineární věčností. Otázka není, zda nachází pro sebe stále nové cesty a zda je mu dáno kráčet všemi novými cestami stále donekonečna, či zda se kroky jeho pleskajících dlaní rozléhají na všech cestách stejně v jediném okamžiku. Není to otázkou zejména proto, že Klíma-filozof se netáže. Tam, kde Nietzsche pozvedal kladivo, on pozvedá meč. ${ }^{15}$ Úkolem praktikujícího egodeisty je smrt a čas porazit, nahlédnout za jejich děsivost, pochopit je jako iluzorní. ${ }^{16}$ A to třeba i za cenu vytrvalého zpřítomňování iluze vlastní smrtelnosti. ${ }^{17}$

14 L. Klíma, Český román a jiné texty, Praha: Levné knihy KMa 2006, s. 213.

15 „Dosud pokoušeli se filosofové, tito trpěliví pavouci, gordický uzel filosofie rozplésti; ale na tento uzel žádná trpělivost nestačila.“ L. Klíma, Svět jako vědomi a nic..., s. 19.

16 Hrdina Klímova Velkého románu, Cesare, tak činí při setkání se Smrtí: „Cesare střetl se s dámou... V celém svém životě nepoznal takové hrůzy, ba i strachu, jako ted', když hleděl na divý, strašidelný obličej putující mrtvoly - tento extrakt vší hrůzyplnosti. Lev z povzdálí strašlivě řval... Ale hned stalo se, co Edgar, jak čtenář pamatuje, řekl: Cesarea zmocnil se stud ještě větší než hrůza, pěsti jeho se zataly, obočí svraštilo, a jediným mávnutím jisté vůle rozplašen byl temný stav jeho duše... Místo jeho zaujal, jak bývá u mužných duchů, prudký vztek..." L. Klíma, Velký roman [sic]..., s. 114.

17 „Zachránila mne mnohokrát - mne oslepivšího se - před smrtí - dostal jsem se, běže téměř a na zenit hledě, v Alpách až na kraj propasti, - vím, že jsem ji nemohl vidět -, a přece náhlý jakýsi šok hodil mne nazpět - krásný pocit; ještě krok - a letíš tak $500 \mathrm{~m}$ dolů -... V nejtemnějších nocích lezl jsem po skalách, - když jsem se pak ve dne na ně díval, udělalo se mně nevolno - ve dne nebyl bych chtěl na ně šplhat -“ L. Klíma, Vteřiny věčnosti..., s. 283. 


\section{Závěr}

Klímův výklad času je závislý na dvou pozicích, které vưči své filozofii musel zastávat. Jednak je součástí výkladu světa (který je vědomím a ničím) a zde lze analyzovat jeho pojetí mýtu o věčném návratu. A také je odhalit jako myšlenkově nesoudržné.

Avšak toto pojetí přestane být problematické, nechápeme-li ho jako explanaci zakoušeného světa, ale jako zvěstované proroctví specifické konfese. Jejím obsahem je výzva k prolomení se životní praxí za iluzi času, beznohého žebráka. Ve výkladu konfese je snad myšlenkový přehmat, ovšem věroučné mýty nelze poměřovat na škále obsahové soudržnosti. Jejich smyslem je fascinovat, zakouzlovat odkouzlený svět. A v tomto byl Klíma pravým prorokem.

\section{PhDr. Jan Kratochvíl}

Pracoviště historické sociologie, Fakulta humanitních studií, Univerzita Karlova

U Křiže 8, 15800 Praha 5, Česká republika

jan.kr@centrum.cz 